\title{
Úton a modern közpénzügyi menedzsment felé
}

\section{Kovács Árpád: Vázlatos betekintés a közpénzügyi döntéshozatalba Oktatáskutató és Fejlesztő Intézet, Budapest, 2014, 307 o.}

Ez a könyv elismerésre méltó hozzájárulás az utóbbi időben gazdagodó közpénzügyi irodalomhoz. A hozzájárulás fö érdeme abban foglalható össze, hogy a szerző jól ötvözte gazdag gyakorlati ismereteit az elméleti tudásával. Műfaji szempontból ez a megoldás nem kockázatmentes vállalkozás, hiszen a tudomány képviselői sokallhatják a gyakorlati példákat, a gyakorlat oldalán állók ugyanezt mondhatják az elméleti fejtegetésekről. Pedig ha valahol, akkor e területen igazán megtermékenyítő a gyakorlat és az elmélet állandóan megújuló együttműködése.

A kötetet ismertetve elsőként néhány olyan összefüggést és tényt emelek ki, amelyek az elmúlt év során különösen éles megvilágításba kerültek. ${ }^{1}$

A könyv 3. fejezete összekapcsolja a költségvetést - illetve szélesebb értelemben a közpénzügyi menedzsmentet - az ország versenyképességével. „Magyarország a válságot követő években tendenciaszerủen rontott versenyképességi helyezésén, hiszen a 2014-ben nyilvánosságra hozott rangsor szerint a 63. helyet foglalta el." (144. o.) Ez annak ellenére következett be, hogy az eltelt időszakban alapvetően jók voltak a költségvetési mutatóink. Mindez pedig arra utal, hogy a közpénzügyi menedzsment minőségének és az ország versenyképességének a kapcsolata sokkal összetettebb annál, mint ahogyan első látásra tünik. Nagyra értékeljük a költségvetési felelősség növelésére tett modernizációs lépéseket is (amelyeknek szükségessége mellett a szerző remekül érvel a 184-194. oldalon), de a lelkesedésünk lankadni kezd, amikor azzal szembesülünk, hogy Magyarország 2015-ben három helyet rontva még lejjebb csúszott a korrupciós rangsorban. Az Európai Unión belül mi rontottunk a legtöbbet a helyezésünkön, és a közösség korrupcióval legfertőzöttebb országai közé kerültünk, azok után és annak ellenére, hogy müködni kezdett a költségvetési felelösségi rendszer (Versenyképesség... [2016]).

A 182. oldalon olvasható minősítés is bizonyos értelemben új megvilágításba került az elmúlt év folyamatainak tükrében. A szerző megállapítása a következő:

\footnotetext{
${ }^{1}$ A sors fintora, hogy - a kormány bürokráciacsökkentő programjának részeként - a könyv megjelenése óta az annak kiadását gondozó Oktatáskutató és Fejlesztő Intézet is rákerült a megszüntetendő, majd a beolvasztandó intézmények listájára.
}

A kézirat első változata 2016. március 7-én érkezett szerkesztőségünkbe. DOI: http://dx.doi.org/10.18414/KSZ.2016.5.588 
„A növekedés ... az országok többségében 2010-2011-ben visszatért, és ezt követően az európai átlag felett alakult - Magyarország és Szlovénia kivételével. Az utóbbiban a válság 2013-ban tovább mélyült, míg nálunk növekedési fordulat következett be, amit a pénzügyi stabilitás megteremtése alapozott meg." A pénzügyi stabilitás irányába tett lépések valóban nagy eredménynek számítottak a könyv megjelenésének idején is, de a növekedési fordulattal kapcsolatos minősítést már akkor is sok szakértő vitatta, és ez a vita nem zárult le az elmúlt egy év alatt sem. Éppen egy közelmúltban tartott konferencián ${ }^{2}$ alakult ki éles vita ebben a kérdésben, ahol a közgazdász szakma megjelent képviselői ennek az ellenkezője mellett érveltek. Ezek a közgazdászok azt emelték ki, hogy a mindenképpen elismerésre méltó makrogazdasági adatok mellett a tartós és fenntartható növekedés feltételei (normateremtő intézmények, humán tőkébe való beruházás, korrupciómentesség és versengő piacok jelenléte) még mindig hiányoznak.

Ezek után foglaljuk össze a könyv fö tartalmi elemeit. A kötet címében szereplő „vázlatos betekintés” egy „kitekintéssel” kezdődik, amikor is a szerző - az 1. és a 2. fejezetben - a közpénzügyi döntéshozatalt elhelyezi az állami szerepvállalás keretei között, és részletesen foglalkozik a modern közpénzügyi menedzsment funkcióival, lehetőségeivel és korlátaival. A leírás elméleti keretét az állam gazdasági szerepe és a közpolitika kapcsolatáról írottak adják. Ebben a keretben megtaláljuk a költségvetési politika, a közpénzügyi menedzsment, a társadalmi haladás, a fenntarthatóság, a pénzügyi politika, a gazdaságpolitika, a szakpolitika fogalmát, és megismerhetjük mindezek gyakorlati megjelenését. Például a költségvetési politikát a szerző az állam gazdasági szerepének érvényesítéseként határozza meg, és a gazdaságpolitika egyik eszközének, a pénzügypolitika részének tekinti. Kovács Árpád nagyon diplomatikusan nem foglal állást az állami szerepvállalásról folyó vitákban megjelent irányzatokkal kapcsolatban. Nagyon helyesen abból indul ki, hogy „napjainkban az állam szerepe tartalmában, kereteiben és kiterjedtségében újra megfogalmazódott” (63. o.). A szerző mind elmélettörténeti megközelítésben, mind saját szakmai élményei alapján körbejárja a témát. Levezetései nem támasztják alá azt az utóbbi időben nálunk erősödő felfogást, hogy „csak az erős állam képes arra, hogy polgárainak megélhetést, munkát teremtsen, a bajba jutottakat segítse" (Lentner [2015] 459. o.).

A szerző a közpénzügyi menedzsmentet a költségvetési politika gyakorlati megvalósításának eszközeként definiálja. A költségvetési politika és a közpénzügyi menedzsment igényes elemzéséből számomra két szempont hangsúlyozása volt különösen figyelemreméltó. Az egyik annak kiemelése, hogy a közpénzügyi döntéshozatal végső célja a közjó szolgálata, azaz annak a kérdésnek a megválaszolása, hogy a sok érdek között hogyan lehet jogszerüen és méltányosan megteremteni az egyensúlyt, hogyan lehet megvédeni az örökölt természeti, kulturális és gazdasági javainkat - és mindezt fenntartható és átlátható módon. Ugyancsak helyeselhető, hogy a szerző folyamatosan szem előtt tartja azt, hogy bár a költségvetési politika az európai integrációban megtartotta relatív önállóságát, müködése

\footnotetext{
${ }^{2}$ Ez már tartós növekedési pálya? A Világgazdaság napilap évindító konferenciája. 2016. január 26.
} 
elválaszthatatlan a globalizált környezettől. „Ezeket a mind gyakrabban nemzetállami kereteket túllépő, stabilitási érdekek vezérelte vállalásokat, »kényszerszolidaritási« kötelezettségeket szervezni, szabályozni, intézményeit müködtetni, önmagában is újszerü és igen összetett, mind ez ideig soha nem látott érték- és érdekharmonizációt igénylö feladat." (64. o.)

A közpénzügyi menedzsmenttel összefüggésben a szerző részletes elméleti hátteret ad a menedzsment lényegének megértéséhez, amelynek része az állami funkciók változásának bemutatása, az alkalmazható minták (új közmenedzsment, jó kormányzás, jó kormány) bemutatása. Öszinte értékelést találunk itt a magyar mintakövetés cikkcakkjairól, a saját út kereséséről, a belső determinációkról. A 92. oldalon szó van a folyamat részeként a politikai-gazdasági elitváltásról, továbbá, hogy „az új, mindinkább kiteljesedő, alapvető államháztartási szerkezetváltozást hozó modell leginkább a »jó kormány " paradigmájának felel meg”. Vajon ez az új megközelítés hogyan fogja szolgálni a közjót? Erre a kérdésre az explicit válasz megfogalmazását a szerző sem vállalhatta. A szerző szavaival: „az adott külső és belső feltételek között sikerül-e a korábbiaknál nagyobb társadalmi-gazdasági hozadékot elérni vagy sem". Egyetértek ezzel az állásponttal, de - a nemzetközi tapasztalatok alapján - kiegészíteném néhány szemponttal.

Az elmúlt évtized végére kialakult pénzügyi és reálgazdasági válság valóban kihívást támasztott a költségvetési menedzsment számára is. Egyfelöl felerösödött az a követelmény, hogy az állam vállaljon nagyobb szerepet a válságmenedzselésben, alakítson ki új együttmüködési formákat a civil szférával, illetve a magánszektorral. A minden eddiginél nagyobb takarékossági igény viszont visszahozta a már meghaladott új közmenedzsment egyes javaslatait (adósságleépítés, költségtakarékos közszektor). A tapasztalatok arra utalnak, hogy az új kormányzási irányzatok javaslatai akkor lehetnek eredményesek, ha a korábbinál jobb koordináció alakul ki mind a kormányzaton belül, mind a kormányzat és a piaci szektor között. Mindez olyan új dimenziókat hoz be a közpénzügyi rendszerek reformjának világába, mint a folyamatos bizalomépítés, a kohézió erösítése a közszektor szereplöi (a kormányzat, a piaci és a civil szféra) között.

Nagy élmény, amikor egy szakmai kérdésről olyasvalakitől olvashatunk, aki annak a témának kezdeményezője és gyakorlati megvalósítója volt. Ez történik a költségvetési tervezés új vonásairól és folyamatairól szóló 4. fejezet esetében. Világos érvek szerepelnek a könyvben arról, hogy mik voltak a szabályalapú fiskális politika bevezetésének költségvetési és reálgazdasági indokai. Meggyőző annak a bemutatása is, hogy mennyire fontos volt a négy pillér (költségvetés-politikai szabályozás, eljárási szabályok, átláthatóság és intézményi feltételek) együttes kezelése. Néhány év elmúltával azonban már lett volna „történelmi távlat” azoknak a cikcakkoknak a bemutatására, amelyek a költségvetési felelősségi keretrendszer kialakításában lezajlottak. Kár, hogy ez elmaradt. Fontos értéke viszont a könyvnek a nemzet(gazdaság)i tervek, programok és intézmények rendszerszemléletü kezelése. Jó lenne, ha ez a gyakorlatban is így történnék. 
A költségvetés végrehajtásáról szóló 5 . fejezetben részletes képet kapunk a végrehajtás ellenörzésében fontos szerepet betöltő intézmények (ÁSZ, KEHI, önkormányzati belső ellenőrzés stb.) működéséről. Itt két pontot szeretnék kiemelni. Az egyik a költségvetési terv minősége és a végrehajthatósága közötti kapcsolat, a másik pedig az információs rendszer működése. A tervek minősége nagymértékben függ attól, hogy mennyire sikerül a kidolgozás folyamatában harmonizálni a politikai és a szakmapolitikai akaratot. A végrehajtás menetében pedig annak lesz jelentősége, hogy a politikai milyen válaszokat tud adni a végrehajtás idején fellépő külső és belső feltételek változására, illetve hogy a szakmai apparátus mennyire képes menedzselni a változtatásokkal járó feladatokat. Természetesen, ha a végrehajtás menetében nem lépnek föl váratlan tényezők, akkor a szakmai apparátus felelössége nagyobb, mint a politikáé, hiszen a végrehajtás eredményessége a szakapparátusok következetességén, szabálykövető fegyelmén múlik.

Az információs rendszer az elmúlt évek korszerüsítő törekvései ellenére még mindig sok problémával terhes. A szerző ezeket áttekintve ír a rendszer dezintegráltságáról, az átláthatóság követelményének sérüléséről, a pénzforgalmi és eredményszemlélet összehangolatlanságáról. Az átláthatóság fontosságát magam is kiemelném, mert szeretnék rávilágítani ennek szakmai és társadalompolitikai vetületére. Szakmai szempontból az átláthatóság hiánya nehezíti az idősoros elemzéseket, a nemzetközi összehasonlíthatóságot, egyes tételek (például a feltételes kötelezettségvállalások) korrekt számbavételét. Nagy baj van akkor, ha csak az adatgazda tud eligazodni a különböző évek adatai között! A közpénzek esetében megkövetelhető lenne, hogy ne csak a szakemberek, hanem az „egyszerü állampolgárok” is könnyen eligazodjanak az adatok között. Egy polgárbarát információs rendszernek persze az is alapfeltétele, hogy a közpénzekkel kapcsolatos adatok ne legyenek titkosak. A másik fontos átláthatósági követelmény, hogy mindenki számára legyen világos a közpénzek elköltésének társadalmi hatása. Az előzetes hatásvizsgálat ma már minden demokratikus állam költségvetési müködésének alapkövetelménye. Jó lenne, ha ez nálunk is általánossá válnék.

A szerző az információs rendszer problémáit korrekten és szakszerűen mutatja be. A tervezett változtatások jó irányba mutatnak (a pénzforgalmi és az eredményszemléletű elszámolások együttes alkalmazása, új számviteli rend, szakfeladatrend stb.). Nagy kérdés ezzel összefüggésben is, hogy mi és miként valósul majd meg a gyakorlatban...

A bevezetőmben mondottakat megismételve nagyon örülök ennek a közpénzügyi irodalmat gazdagító könyvnek. Korábban már szóltam arról, hogy mennyire nagyra értékelem a könyvnek azt az erényét, hogy összekapcsolja az elméletet a gyakorlattal. Ehhez még azt tenném hozzá, hogy szakmai élmény volt a lábjegyzetek magyarázó, eligazító szövegét olvasni akár valamilyen történelmi utalásról, akár a fogalmak mélyebb magyarázatáról volt is szó.

Végezetül szeretnék egy korábbi recenziómnál idézett mondatot visszahozni ebbe a környezetbe is: „A modern társadalmakban a legkomolyabb dolog a pénz. A demokratikus társadalmakban ennél egy még komolyabb dolog is van: a közpénz." (Sivák [2010] idézi László [1995]-t.) 


\section{Hivatkozások}

LÁszló CsABA [1995]: Tépett vitorlák. Közgazdasági és Jogi Könyvkiadó, Budapest.

Lentner Csaba [2015]: Az új magyar állampénzügyi rendszer - történeti, intézményi és tudományos összefüggésben. Pénzügyi Szemle, 4. sz.

Sivák József [2010]: A közpénzügyek nagy kézikönyve. Complex Kiadó, 2009. Pénzügyi Szemle, 3. sz.

VERSENYKÉPESSÉG... [2016]: Versenyképesség szabadesésben - Romló közállapotok Figyelő, 4. sz. 30-31. o.

Sivák József

Sivák József, a közgazdaság-tudomány kandidátusa.

\section{Kedves Szerzőink!}

Az MTA Könyvtár és Információs Központtal együttműködve cikkeinket ellátjuk a CrossRef-nél regisztrált DOI-azonosítóval. Ezért azt kérjük, hogy a Hivatkozásokban tüntessék fel a hivatkozott művek CrossRef-nél regisztrált DOIazonosítóját (természetesen sokszor előfordul, hogy nincs ilyen azonosító). Ez az azonosító a következő linkre kattintva kereshető meg: http://search.crossref.org.

Például:

Boldrin, M.-Montes, A. [2005]: The intergenerational state: Education and pensions. Review of Economic Studies, Vol. 72. No. 3. 651-664. o.

A hivatkozott tételt bemásoljuk a kereső mezőbe, a találati listából pedig kiválasztjuk a megfelelő tételnél lévő hivatkozást, és beszúrjuk a hivatkozás végére:

Boldrin, M.-Montes, A. [2005]: The intergenerational state. Education and pensions. Review of Economic Studies Vol. 72. No. 3. 651-664. o. http://dx.doi. org/10.1111/j.1467-937x.2005.00346.x.

Ne feledkezzenek meg a beszúrt hivatkozás hiperhivatkozásként való megjelöléséről a kéziratban!

A CrossRef-nél regisztrált DOI növeli a cikkek láthatóságát, könnyíti az adott, kapott hivatkozások összeszámlálását! 